Altun-Könez, N., Çelik-Şahin, A., Apaydın,G., Yılmaz, B., \& Aykut, Ç. (2019). The Effect of Concept Teaching with Embedded Instruction to the Students with Intellectual Disabilities. Bartın University Journal of Faculty of Education, 8(1), 208-230.

Bartın University Journal of Faculty of Education, 8(1), 208-230

Bartın Üniversitesi Eğitim Fakültesi Dergisi, , 8(1), 208-230

buefad.bartin.edu.tr

\title{
The Effect of Concept Teaching with Embedded Instruction to the Students with Intellectual Disabilities
}

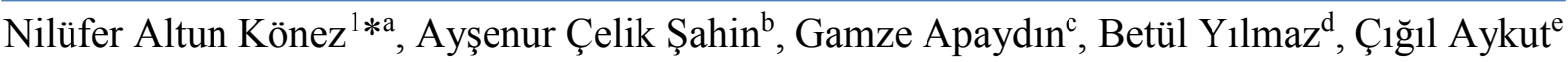

\begin{tabular}{l} 
Article Info \\
\hline DOI: 10.14686/buefad.430011 \\
\hline Article History: \\
Received 02.06.2018 \\
Accepted 24.12.2018 \\
Published 01.02.2018 \\
\hline Keywords: \\
embedded instruction, \\
intellectual disabilities, \\
concept learning, \\
\hline Article Type: Research article \\
\hline
\end{tabular}

\begin{abstract}
The aim of this research is to analyse the effect of teaching half concept embedded in sandwich making skills for the students with intellectual disabilities. The participants of this research consists of three students between the ages of 11 and 14 with mild intellectual disabilities and continue their education in a practice school in Ankara province. In this research, multiple probe design method is used in this single subject experimental design research model. As dependent variable of this research is to teach participants both sandwich making skills and half concept, the independent variable of the research is to teach half concept embedded in sandwich making skills. At the end of the research, the concept teaching embedded in sandwich making skill is effective in acquiring the half concept by two participants in the material of concept measure, but did not work in one participant.
\end{abstract}

\section{Zihinsel Yetersizliği Olan Öğrencilere Gömülü Öğretim Yöntemi İle Sunulan Kavram Öğretiminin Etkisi}

\begin{tabular}{l} 
Makale Bilgisi \\
\hline DOI: \\
10.14686/buefad.430011 \\
\hline \multicolumn{2}{l}{ Makale } & Geçmişi: \\
Geliş $\quad 02.06 .2018$ \\
Kabul $\quad 24.12 .2018$ \\
Yayın $\quad 01.02 .2018$ \\
\hline Anahtar Kelimeler: \\
Gömülü öğretim, \\
Zihinsel yetersizlik, \\
Kavram öğretimi, \\
\hline Makale Türü: Araştırma \\
makalesi
\end{tabular}

Öz
Bu araştırmanın amacı, yarım kavramının sandviç yapma becerisinin içerisine
gömülerek ögretilmesinin, zihinsel yetersizliğe sahip öğrencilerin bu beceri ve
kavramı kazanmalarına olan etkisinin incelenmesidir. Araştırmanın katılımcılarını
Ankara ilinde bir eğitim uygulama okuluna devam eden, yaşları 11 ile 14 arasında
değişen hafif zihinsel yetersizliği olan üç öğrenci oluşturmuştur. Araştırmada, tek
denekli deneysel desenlerden denekler arası yoklama evreli çoklu yoklama deseni
kullanılmıştır. Araştırmanın bağımlı değişkeni, katılımcıların sandviç yapma
becerisini ve yarım kavramını kazanma düzeyleri, bağımsı değişkeni ise sandviç
yapma becerisinin içine yarım kavramının gömülerek öğretilmesidir. Araştırma
sonucunda, üç katılımıının da sandviç yapma becerisini kazandıkları görülmektedir.
Ek olarak yarım kavramının sandviç yapma becerisinin içerisine gömülerek
öğretilmesinin, bu kavramın kazanılmasında iki katılımcı için etkili olduğu; bir
katılımcı için etkili olmadığı görülmüştür. Ayrıca, elde edilen bulgular, katılımcıların
beceriye ilişkin kazanımlarını, uygulama evresi tamamlandıktan dört ve altı hafta
sonra da sürdürdüklerini göstermiştir.

\footnotetext{
1*Corresponding Author: niluferaltun@gmail.com

${ }^{a}$ Res. Assist., Gazi University, Ankara/Turkey, http://orcid.org/0000-0001-8502-0286

${ }^{\mathrm{b}}$ Res. Assist., On Dokuz Mayis University, Ankara/Turkey, http://orcid.org/0000-0001-6346-2294

${ }^{c}$ Res. Assist., Gazi University, Ankara/Turkey, http://orcid.org/0000-0002-1368-8858

${ }^{\mathrm{d}}$ Res. Assist., Gazi University, Ankara/Turkey, http://orcid.org/0000-0002-2633-5592

${ }^{e}$ Assoc. Prof., Gazi University, Ankara/Turkey, http://orcid.org/0000-0002-0365-9930
} 


\section{Introduction}

Concepts are accepted as a basis for the learning process. These are the set of stimuli that leads to common reaction (Özyürek, 1983). Concept learning process of individuals with intellectual disabilities both provides a basis for the academic skills of individuals and helps them to understand objects and events around them (Vuran \& Çelik, 2013). Also, concepts have a vital importance for academic skills of individuals with intellectual disabilities as well as for their daily life skills (Sucuoğlu, 2009).

Individuals with intellectual disabilities need to acquire daily life skills and functional academic skills together with the concepts in order to live independently in the society. Daily life skills consist of all skills which are necessary to meet individuals' needs for personal care and to maintain their lives independently both in the house and the outside (Varol, 2005). Moreover, functional academic skills are necessary for individuals to maintain their lives and work in the society independently (Çifci-Tekinarslan, 2015). The activities aim to teach daily life skills provide an opportunity to teach several concepts and the other skills simultaneously (Varol, 2005). Accordingly, it is stated that daily life skills can be thought together with the functional academic skills (Snell \& Brown, 2000). Collins, Karl, Riggs, Gallowey, \& Hager (2010) suggests that there are six-step implementation process to teach two different skills. First of all, educational objectives are determined according to the needs of students in this process. Secondly, educational environment is planned which is appropriate for the individualized education plan (IEP). Thirdly, an evidence based teaching process is selected. Fourthly, untargeted information is embedded in this educational environment. Fifthly, research data are collected from this teaching process and it is represented in graphics. Lastly, activities are planned and implemented for the generalization and maintenance of these steps.

It is seen in literature that daily life skills and concept learning skills are usually thought separately in segregated education settings where students with intellectual disabilities continue their education (Aslan \& Eratay, 2009; Birkan, 2002; Karabulut \& Yıkmış, 2010). However, Browder, Wakeman, Flowers, Rickelman, \& Pugalee (2007) stated that it is more effective to teach concepts together with daily life skills to students with disabilities and presenting them the tools specifically used in these skills. Naturalistic instructional approach provides an opportunity to teach concepts within daily life skills. Naturalistic approach is a method including, environmental arrangements according to interaction in educational settings based on the applied behaviour analysis (Pretti-Frontczak \& Bricker, 2004). One of the teaching methods of naturalistic instructional approach is embedded instruction. Even though there is no agreed definition on it, embedded instruction is a systematic teaching method which is presented through discrete trial teaching in the classroom routines (Johnson, McDonnell, Holzwarth, \& Hunter, 2004; Riesen, McDonnell, Johnson, Polychronis, \& Risen, 2002). This method provides an opportunity for students to learn the target behaviour by embedding it into daily classroom activities and routines (Aldemir-Frrat \& Ergenekon, 2018). Embedded instruction is mostly seen among evidence based practices in literature, presented its effectiveness through many research activities. Embedded instruction is an effective method that is frequently used in teaching concepts, languages, early literacy and social skills in inclusion settings to the students with disabilities. (Daugherty, Grisham-Brown, \& Hemmeter, 2001; Ducharme, Lucas, \& Pontes, 1994; Grisham-Brown, Shuster, Hemmeter, \& Collins, 2000; Horn, Lieber, Sandall, Schwartz, \& Li, 2000; Jameson, McDonnell, Johnson, Riesen, \& Polychronis, 2007; Pretti-Frontczak \& Bricker, 2001; Simpson \& Keen, 2010; Wolery, Doyle, Gast, \& Ault, 1993). In addition to its effectiveness in various different areas, embedded instruction is quite useful in increasing the generalizability of the learned skills and it can be easily worked with different people and different tools in various environments (Wolery, Anthony, Caldwell, Snyder, \& Morgante, 2002).

According to examination of literature that embedded instruction method is used in different age groups, different educational environments and for teaching different target behaviours. It has been identified that embedded instruction is effective in especially inclusion environments where students with disabilities continues their education and it is seen that the studies are increased in the preschool inclusion settings (Aldemir-Firat \& Ergenekon, 2018). In addition, there are also some researches in which the concepts are embedded in daily life activities to teach students with moderate and severe disabilities. Collins, Hager and Galloway (2011) focused on both methods targeting three middle school students with moderate disabilities by using constant time delay procedure. While classroom teacher follows the IEP to teach the subjects, special education teacher presents the already learned subjects by associating them with the daily life skills of students. In this context, language activities are studied together with functional reading skills, cooking activities are studied with the state of matter in science and shopping activities with calculation skills. Therefore, it is seen that acquisition, maintenance and 
generalization is successfully achieved in these students as a result of studying the instructional objectives together with functional activities. Karl, Collins, Hager, and Ault (2013) aimed to teach academic skills to four middle school students with moderate disabilities in a functional activity by using the constant time delay procedure. In this study, reading appropriate to age level in Turkish, solving percent problems in maths and power problems in science are embedded into cooking activities. At the end of the study, all participants are achieved the academic skills targeted inside the cooking activity. On the other hand, in the study conducted by Collins, Evans, Galloway, Karl, and Miller (2007), functional reading skills are taught to students with moderate and severe intellectual disabilities by using three different methods. These methods are: direct massed trial instruction given in source room, direct distributed trial instruction and embedded distributed trial instruction given in general instruction classes. According to study findings, it is identified that students with moderate and severe intellectual disabilities learned the targeted behaviours with the help of these methods. Furthermore, the acquisition and maintenance of skills in these three methods showed little differentiation compared to general and special education classes.

When we look at the studies conducted, it is seen that the target skills are in the fields such as mathematics, science and Turkish are embedded in daily life skills and learned in inclusive education settings. However, there are limited number of researches proving that the concepts embedded in daily life skills can be taught in segregated education settings. In our country, it is known that education programmes of students who attend in Special Education Practice Schools concentrate on teaching self-care and daily life skills. Considering the fact that daily life skills include in many functional academic skills and it is considered to be more effective to teach them within daily life skills. Being able to use both daily life and functional academic skills together with the materials is crucial in terms of gaining time to the instructors and providing opportunity for students to learn more than one purpose. Considering cost and time efficiency, concepts and teaching these concepts by embedding them into daily life skills are quite important. (Karl, Collins, Hager, \& Ault, 2013). Accordingly, it is considered that presenting the effectiveness and efficiency of the embedded instruction method used in the education of students affected by the disabilities by working with different people in different education settings will contribute to both literature and researchers. The aim of this study is to examine the effects of functional academic skills which is embedded in daily life skills to teach students with intellectual disabilities in segregated education settings. In this context, this study aims to examine the half concept of functional academic skills that are embedded in sandwich making skills of daily life skills.

\section{Method}

\section{Research Design}

In this research, multiple design method is used in this single subject experimental design research model (Tawney \& Gast, 1984). This is a model that an independent variable is examined on three different participants. The beginning level data is simultaneously collected by the all participants and practice starts for the first participant, when determined data is received. As the targeted criterion is fulfilled, full probe session is repeated for all participants and the practice starts for the second participant. As the targeted criterion is fulfilled by the second participant, full probe session is repeated with all participants and the practice starts for the third participant. When the targeted criterion is fulfilled, the full probe session is repeated again (Tekin-İftar, 2018).

\section{Participants and Selection Criteria}

Participants of this research consists of three students, one male and two females with intellectual disabilities who are continuing their educations in a special education and job application centre located in Ankara province between 2015-2016 school year.

For the selection of participants, it has been taken into account that students a) are diagnosed with mild and moderate level of intellectual disability; b) have no additional disabilities apart from their intellectual disabilities; c) are willing to participate in this research and their parents approved their participation; d) can independently use the knife to cut things; e) do not have half concept and did not receive any systematic learning related to this concept; f) can complete two-step instructions; and g) have ability to imitate.

In the selection of participants, it has been firstly interviewed with the classroom teachers and their reports were analysed. The check-lists including mathematical concepts and daily life skills were applied to the students 
who are being considered to meet the criteria. As a result of this applied check-lists, three students who have not half concept and sandwich making skills are included in this study.

Table 1. Demoraphic Characteristics of the Participants

\begin{tabular}{ccccc}
\hline Participant & Sex & Age & Diagnosis & Period \\
\hline 1 & F & 15 & Moderate ID & 8 \\
2 & M & 11 & Mild ID & 4 \\
3 & F & 13 & Moderate ID & 5 \\
\hline
\end{tabular}

First participant is 15-year-old girl with 45-49 IQ score and diagnosed with moderate level of intellectual disability and have $70 \%$ disability report. Second participant is 11 -year-old boy with mild level of disability. Third participant is 13-year-old girl with 35-40 IQ score and with a moderate level of intellectual disability and have $70 \%$ disability report. The duration, regarding the participant's attending to special education practice schools changes between four and eight years.

\section{Dependent Variable}

The dependent variable of this research is the level of having half-concept and sandwich making skills of students with intellectual disabilities. Although students cannot distinguish the half concept from other concepts (loaf and quarter of a loaf of bread), they can easily point at all ingredients used in sadwich making skills. However, they cannot achieve all steps, when they are asked for the instruction: "make sandwich".

\section{Independent Variable}

The independent variable of this research is to teach half concept embedded in sandwich making skills. In this teachning process embedded instruction is presented with a modelling clue.

\section{Practitioners}

The implementation and probe sessions were carried out by the $4^{\text {th }}$ grade students of department of education for the intellectual disability. These students continue their internship as a teacher candidate in a special education and job application centre within the scope of teaching practice courses. All teacher candidates received courses on skill and concept teaching for people with intellectual disability in their undergraduate classes and received theorotical information in regard to embedded teaching method in this course. However, they have no experience in practicing. However, trainings were provided for these teacher candidates on embedded instruction by the researchers. Theoratical trainings were carried out three hours in two consecutive days, while on-the-job trainings lasted in three sessions with two days a week. In this training, firstly the articles explaining the practices of embedded instruction were provided to teacher candidates in addition to lecture notes and the content of these articles were discussed together with the candidates. Hence, the theoretical knowledge of the candidates about embedded instruction were enhanced. Then, the sample videos focusing on the embedded instruction were displayed and explanations were made on the practice of embedded instruction through these videos. Accordingly, for a preliminary preparation, a practice was made with students among participants and this is observed by all candidates. In this process, the instructors were immediately interrupted the practice and provided feedbacks about the practice of teacher candidates. When teacher candidates become able to carry out teaching process in the embedded instruction without any need to correct and feedback to their teachings, the implementation process of the research is started.

Maintenance sessions are carried out by the instructors who carry out the teaching practices as the first, second and third writers of this research. The instructors have experience in teaching and have at least 2 years of experience in providing embedded instruction practices. The reliability data of research was collected by an independent researcher who has a Master Degree in Department of Education for the Intellectual Disabilities, and has an experience in teaching and embedded teaching practice. Before analysing the reliability data, trainings were provided for the observer to show how the procedure will be realized. 


\section{Setting, Time and Materials}

This research was carried out one-to-one format in a study room and the kitchen of the school where participants continue their education. During the implementation process, teacher candidate and the participant worked one to one. While study room is approximately 12 square meters, the kitchen is approximately 25 square meters. In the study room, there is table which is height enough for the participants and two chairs for both the participant and the teacher candidate and lastly a table for the placing the necessary materials. In the kitchen, there are oven, refrigerator, table, eight chairs, a counter, kitchen cupboards, and utensils.

With the aim of teaching half concept by embedding in the sandwich making skills, instruction sessions of this research is carried out two times in a week and once in a day in school's kitchen. Instruction sessions lasted 30 minutes. Full probe sessions were carried out in one to one study room for sandwich making skills 30 minutes, while acquiring half concept skills lasted 10 minutes.

While the real objects were used in instruction session of this research, there were both the real objects and the pictures of them used in probe sessions. In instruction sessions, bread, tomato, cucumber, lettuce, sliced cheese and salami were used as real objects.

\section{Data Collection Tools}

The data collection tools used in this research are; starting level and the criterion-dependent measurement tool for the half concept in the probe sessions and the sandwich making skills for the sandwich making. The half concept consists of six notices. In the first column of this criteration-dependent measurement tool, there are reports on unrelevant qualities of the concept. In the second column, there is a criteration where the accuracy percentage is given and in the third column there are questions to measure, while there is register section where the responses of students are recorded in the last coloumn.

Sandwich making steps are listed according to the analysis and orderings of the person who is able to accomplish this achievement. It has been consulted to two special education experts and the analysis are finalized as per the views of them. The skill of making sandwiches is composed of 16 steps. These steps are written in the criteration-dependent measurement tool notices column, accuracy level of the target behaivor is written in the criteration coloumn, instructive questions related to achievement of the skills written in the question coloumn and lastly, responses of the students is placed in the register coloumn.

\section{Research Design and Implementation}

In this research, multiple probe design method is used in this single subject experimental design research model (Tawney and Gast, 1984). The implementation process of the research consists of probe, instruction, maintenance and generalization sessions. The implementation of each session are described in detail below.

\section{Implementation Process}

Implementation process of the research consists of full probe, maintenance and generalization sessions. The implementation of each session is explained below in detail.

\section{Full Probe Sessions}

In this research, full probe sessions related to half concept and sandwich making skills are executed for each participant before and after the instruction. The half concept criterion-dependent measurement tool and the real objects and both the objects and the pictures of them in sandwich making skills, criterion-dependent measurement tool are used in each full probe session. Half concept is accepted as $3 / 4$ criterion by criterion-dependent measure. For sandwich-making skills, the level of achievement of each skill step has been determined.

Full probe sessions were held on individual basis with the participants. During these sessions, remained unresponsive to the participants' all answers. Collective full probe sessions were executed for all participants by using similar operation processes.

\section{Instruction Sessions}


In embedded instruction sessions where the modelling clue is used, the need for teacher candidate to exhibit the students' knowledge in half concept is created and the attention is drawn into study. For instance, at the first class, the teacher candidate asked to participant: "We came to school early in the morning, we might not have breakfast, I am hungry, how about you?" has established requirements such as establishing interaction. In that case, the teacher candidate said "Let's have our breakfast, so what do we have to eat?" Therefore, in that way interaction is formed and the participant is encouraged to look at the ingredients. The teacher candidate showed the ingredients in the fridge and said "I think, we can make sandwiches with the ingredients here, I like it very much, do you like sandwiches?" Accordingly, the teacher candidate starts making by asking the participant: "Let's start making sandwiches?". During the instruction, the teacher asks the participant to perform the skill step as a model for the skill steps. The teacher candidate asked to participant: "Now watch me carefully. I place the cutting board, plate, knife and napkin on the counter. Now do the same thing that I did". Thus, the teacher candidate made a presentation by drawing attention to the work where the half concept is embedded in the skill level. The teacher candidate took a loaf of bread and said "Oh, there is a loaf of bread here. A loaf of bread is too much for one person. It would be better if we make sandwiches with half of the bread." And then, teacher candidate cut the bread by saying "Now I cut a loaf of bread with a knife in half". Accordingly, he stated that "Look, we have two halves a loaf of bread now. We make sandwiches with half of a loaf of bread. This is half of a loaf of bread. Let's do what I do". Thus, the teacher candidate presented a model for both the negative and positive examples of the half concept. Following the model clue presented by the teacher candidate, the correct responses of the participant are reinforced by describing in detail. For the incorrect responses, it is required from the participant to repeat these skill steps by using verbal clues. If the participant cannot do it even after the verbal clue, modelling clue is used on this skill and asked the participant to do it again accordingly. In cases where the participant is unresponsive, the teacher candidate repeats the instruction and if the participant cannot do it again, modelling clue is used to encourage the behaviour. For each instruction, this teaching method is repeated. For negative responses of the participants, the skill step is asked to be repeated by using modelling technique. For the cases where participants are non-responsive, teacher candidate repeats the instruction and uses modelling clue, if the participant does not perform it again. For each teaching step teaching presentations are repeated.

After instruction sessions, end-of-practice evaluation sessions are organized related to half concept and sandwich making skills every day. In these sessions, responses to the half concept are recorded by using the photos of ingredients used in sandwich making skills. The level of success for each skill step has been determined for the sandwich making skills. These sessions are carried out one-to-one with the all participants.

\section{Maintenance and Generalization Sessions}

After instruction sessions are over, maintenance sessions are organized to determine the level of sustainability of the students of which the behaviours learned in related to half concept and sandwich making skills. These sessions are realized in 4 and 6 weeks after the end of instruction sessions in the same instruction setting as it is carried out in collective full probe sessions.

The generalization sessions are carried out by different people with the participants on individual bases in the instruction settings where the practice sessions are completed. These two people were the instructors who conducted this research.

\section{Reliability Analysis}

The reliability data of this study are collected in two different ways one of them is inter-observer reliability and the other is implementation reliability. Inter-observer reliability and implementation reliability are collected for each participant in $30 \%$ of the full probe, instruction, maintenance and generalization sessions by following random method approaches.

\section{Inter-observer Reliability}

The reliability data is coded by the evaluation of one of the researchers and an independent researcher who is involved in the research. Before encoding, the researcher introduced a criterion-dependent measurement tool for both concept and sandwich-making skills on an example video. Accordingly, it is asked to analyse the interobserver reliability data by given $30 \%$ of these application videos. The data of this study are recorded as "+" and "-" in the measurement tools according to the targeted behaviours presented by the participants. Inter-observer reliability in this study is calculated as "agreement / (agreement + disagreement) X 100" (Tekin and Kircaali-İftar, 
2001). It has been identified that the percentage of inter-observer reliability for the half concept and sandwichmaking skills of the first participant is $91 \%, 93 \%$ for the second participant and lastly $96 \%$ for the third participant.

\section{Instruction Reliability}

Instruction reliability data are collected to determine whether the teaching processes is carried out as it is planned in the study. In order to calculate the reliability, instruction reliability data form including practice steps and instructor's behaviours is prepared. This form is given to independent researcher and the form is fulfilled together by watching the sample video. A sample video was provided for an independent evaluation and asked from the researcher to fill the form according to it. When the data are consistent at $80 \%$ level independently, the observer is asked to analyse the instruction reliability data by providing $30 \%$ of the actual application videos. It is asked to mark the performed steps with "+" and unperformed steps with "-"” in the record data table. The research's insruction reliability is calculated in line with the formula "observed instructor behaviour / projected instructor behaviour X 100" (Tekin and Kırcaali-İftar, 2001). The reliability data of the practice is found 100\%.

\section{Social Validity}

The social validity data of this research is collected through interviews with the teacher candidates who carried out application process of this research. Related to teaching of the half concept embedded in sandwich-making skills, the following questions are asked to teacher candidates: a) what are their opinions in embedded instruction? and b) what are their opinions in teaching daily life skills together with half concept? Teacher candidates stated that embedded instruction approach is not only flexible and easily applicable in teaching process, but also it provides natural presenting settings. Furthermore, they stated that it is quite effective and efficient to teach daily life skills together with the concepts: in addition it might be more efficient to present various daily life skills together with concepts.

\section{Data Analysis}

Data acquired at the end of this research is graphically analysed. In the graphics of this research, $\mathrm{Y}$ is the axis where quantiative dependent variable is defined and the percentages of correct responses for sandwich making skills and half concept are presented. $\mathrm{X}$ is the axis where the sessions are presented. The data abtained at the end of each session quantatively presented in the graphic $\mathrm{x}$. The distance of $\mathrm{X}$ axis from the $\mathrm{Y}$ axis visually reveals the effect of independent variable on dependent variable (Tekin-İftar, 2018).

\section{Findings}

In this study, the effect of teaching half concept embedded in sandwich making skills for the students with intellectual disabilities are analysed. Findings of this research is presented in Graphic 1 and Graphic 2. 


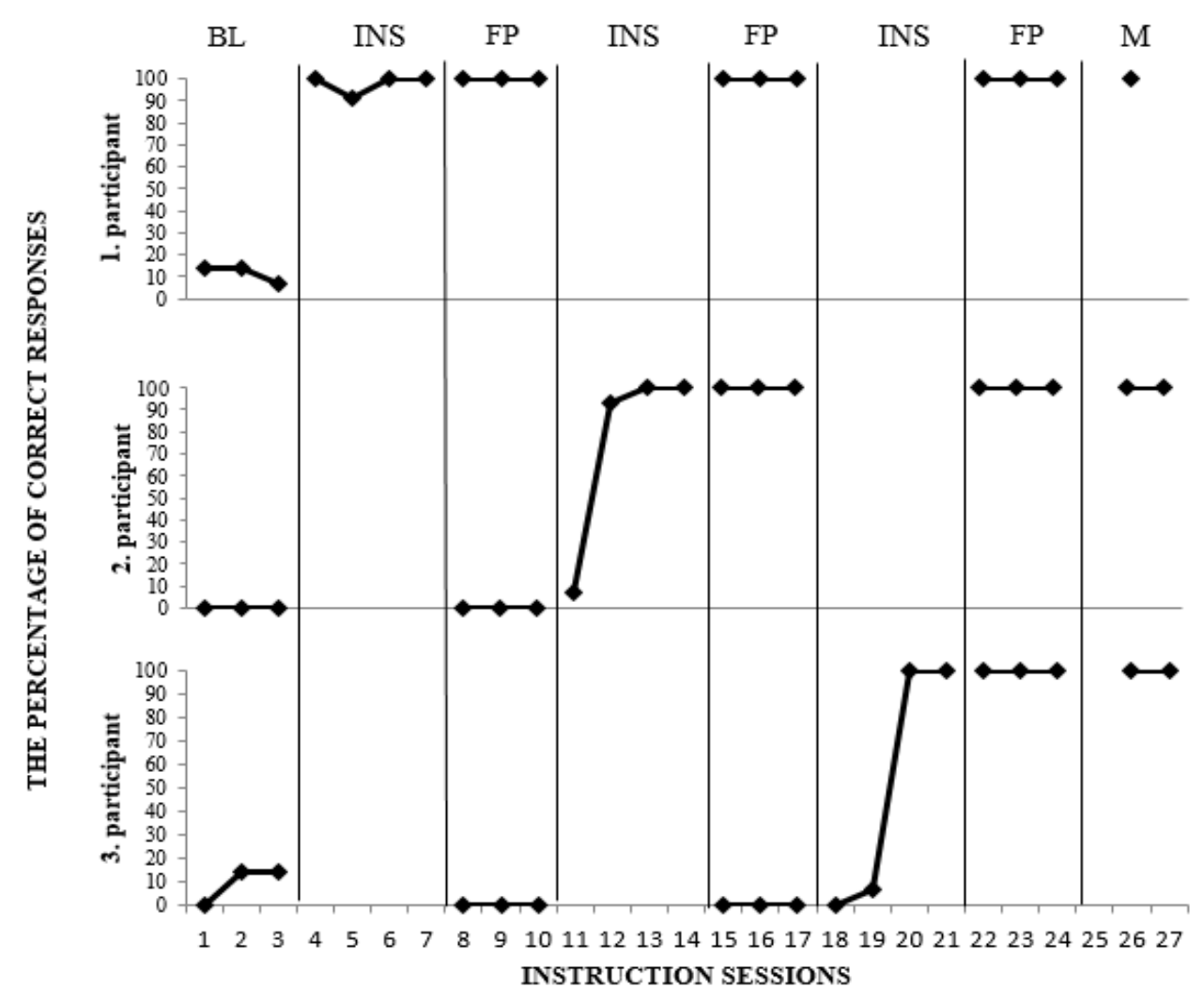

Graphic 1. The percentage of sandwich-making level of the participants

As it is seen in graphic 1, three participants in the study could not independently perform sandwich making skills at the beginning level. At the end of the implementation process, it is seen that the level of success of all three participants is $100 \%$. At the end of four sessions, these three students fulfilled the criteria for sandwich making. Four instruction sessions were executed until each participant meets the targeted criteria. Four weeks after the first participant's instruction session, it is observed that sandwich making skill of the first participant is $100 \%$ in maintenance session. This participant could not attend the second maintenance session due to the last of attendance at the school. In the maintenance sessions of the second and third participants realized four and six weeks later, it is seen that performing sandwich making skills is $100 \%$. These results show that all participants maintained their level of success in terms of performing sandwich making skills after receiving instructions on sandwich-making skills through modelling clue. 


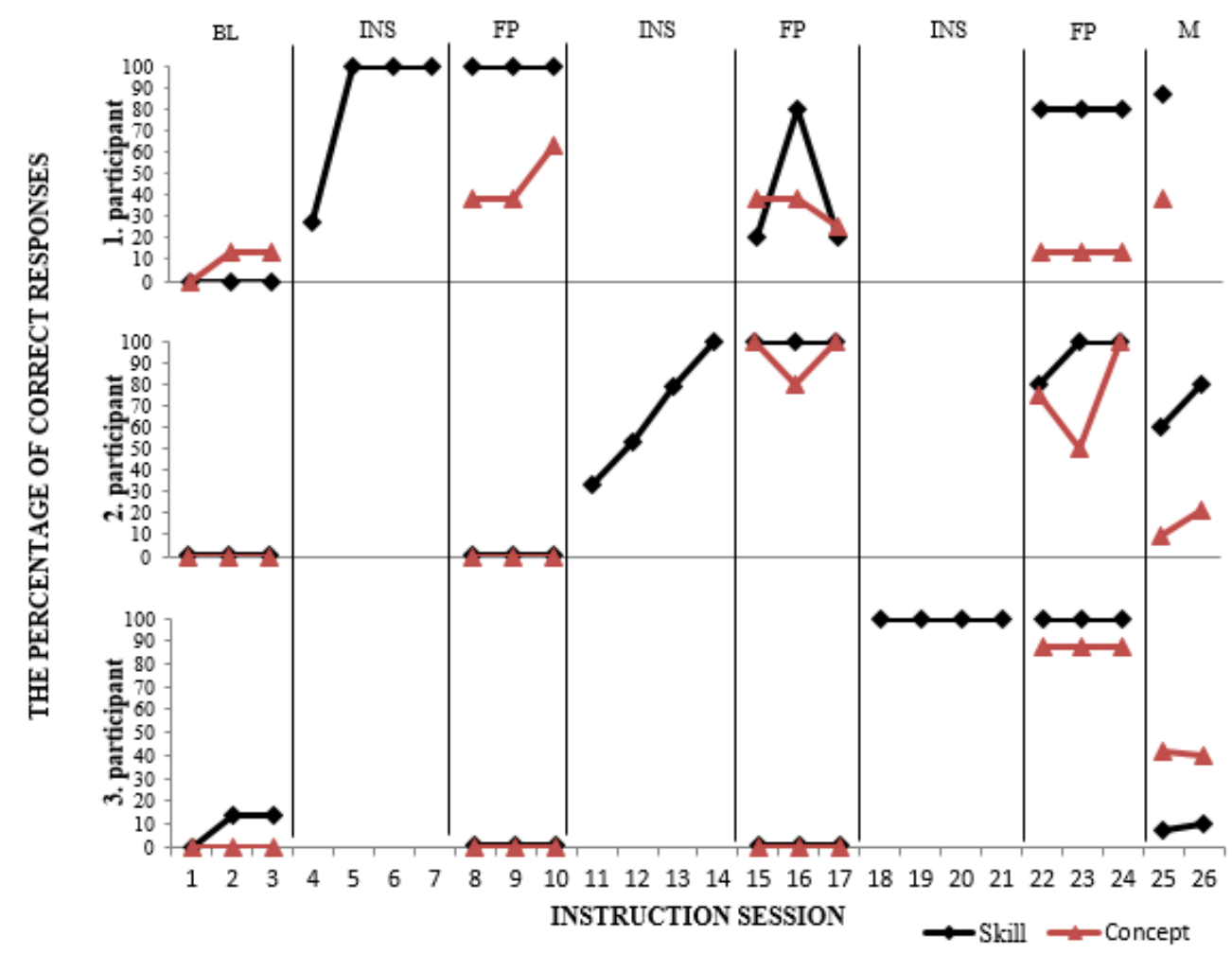

Graphic 2: The percentage of the performance of participants achieving half concept embedded in sandwich making skills through used ingredients prepared for the criterion-dependent measurement tool.

As it is seen it Graphic 2, all participants could not perform the half-concept given in criterion- dependent measurement tool independently at the beginning level. It is observed that the level of participant's performing the half concept given in critarion-dependet measurement tool is $100 \%$ with the skill materials at the end of instruction evaluation sessions (skill- ). However, when full probe sessions are analysed, the performance level of first and second participant presenting the half concept with materials is $80 \%$, while the third participant's level of performance is $100 \%$. For the materials prepared according to criterion-dependet measurement tool in full probe sessions (concept $\leftarrow$ ), first participant's level of performance is $10 \%$ in average, while second participants' performance is $75 \%$ in average, and third participant's performance is $90 \%$ in average. These results show that two students are gained half concept skill in acquitance level, yet only one student could not have learned the concept.

When maintenance sessions are analysed, it is seen that sandwich making skill of the first participants is $100 \%$ after implementation sessions ends at the end of four weeks. And, performing half concept level is calculated as $40 \%$ by using the materials prepared in accordance with the criterion-dependet measurement tool. This participant could not attend the second maintenance session due to the lack of attendance at the school. In maintenance sessions that are operated in four and six weeks after the end of instruction sessions, the level of performing half concept of the second participant by using the ingredients for sandwich making is $80 \%$. And, the level of concept instruction with the materials prepared in accordance with the criterion-dependent measurement tool is $20 \%$. In maintenance sessions whic are operated in four and six weeks after the end of instruction sessions, the level of performing half concept of the third participant using the ingredients for sandwich making is $10 \%$. And the level of concept instruction with the materials prepared in accordance with the criterion-dependent measurement tool is $40 \%$. Both with the skill teaching materials and the general evaluation materials for the concept in the maintenance sessions are taken with the criterion-dependend measurement tool. It has been observed that the first and second 
participants maintained the concepts with teaching materials, while the third participant could not maintain the the level that is reached with these materials at the end of concept teaching. And none of them have acquired permanence with the materials prepared according to concept criterion-dependent measurement tool.

\section{Discussion and Results}

In this research, the effect of teaching half concept that is embedded in sandwich-making skill for three students with intellectual disabilities who are continuing their education in the special education and job application centre setting is analysed. It is considered that there are several significant results of this study. As research findings are examined, it is seen that three participants acquired sandwich making skills and gained permanence of this skill. Furthermore, it is observed that all three participants gained half concept embedded in sadwich making skills together with the materials provided for teaching. These indings suggests that sandwich making skills of daily life skills are effective in both sandwich making and half concept acquisition that is embedded within functional academic skill. This shows similarity with some of the research results in literature (Collins, Evans, Galloway, Karl, \& Miller, 2007; Collins, Hager, \& Galloway, 2011; Jameson, McDonnell, Johnson, Riesen, \& Polychronis, 2007; Johnson, McDonnell, Holzworth, \& Hunter, 2004; Karl, Collins, Hager, \& Ault, 2013). Secondly, although the concept was acquired by all participants with skill teaching materials, the different findings of the participants related to generalization of the concept to materials given in the criteration-dependent measurement tool is noteworthy. It seen that the second and third participant acquired the half concept embedded in sandwich making skills through concept measuring, yet it is seen that the first participant's concept level still remained at the level of $10 \%$. It is because of the fact that although three participants gained the half concept with the materials that are used to teach skills, they could not generalize this concept to different materials. Also, the half concept is presented in only one skill and the materials could not have diversified in instruction sessions. Additionally, the number of instruction sessions could not be increased due to the fact that the application period coincides with the end of academic year. However, it is observed that sandwich making skill is successfully generalized by the all participants. This is especially due to the fact that the training was carried out in early in the morning as a natural reinforcement for the participants and motivated them as a daily life skill.

All these findings prove that considering the characteristics and existing status of students in special education practice schools, teaching embedded instruction with daily life skills and functional academic skills will be an example for teachers and will bring valuable contributions to the literature. In national literature, it is seen that, studies related to embedded instrruction are quite limited and embedded instructions are mostly executed within activities. (Altun-Könez, Çelik, Yılmaz, Apaydın, \& Aykut; 2015; Berkeban, 2013; Eren, Deniz,\& Düzkantar, 2013; Kurt \& Tekin-İftar, 2008; Odluyurt, 2010; Odluyurt, 2011; Rakap \& Balikci, 2016; Şahin, 2015). However, this research is considered as quite significant for teaching the concept in segregated learning environment and within the daily life skills. The concept teaching embedded in skills has not only positive effects for students but there are several advantages for the trainers as well. Teaching concepts together with daily life skills enable teachers to teach more things in less time. This research is restricted with one concept teachning by only embedding it in one daily life skill. Furthermore, teachers can teach the concept by embedding it into many different skills and routines in accordance with the students's needs. In addition, the materials used in teaching might be divesified or increased to make students to generalize the different materials. Some different researches might be carried out in further studies focusing on multiple academic skills embedded in one skill or multiple skills embedded in one academic skill. Moreover, various researches can be carried out in the form of teaching different concepts embedded into daily life skills individually or in small group activities together with students from different ages. The effectiveness and efficiency of these studies can be examined by educating the teachers with different professional development models and embedded instruction.

\section{Acknowledgement}

The research was presented as a verbal announcement at the 26th National Special Education Conference, held on 5-8 October 2016 at Anadolu University. 


\title{
Zihinsel Yetersizliği Olan Öğrencilere Gömülü Öğretim Yöntemi İle Sunulan Kavram Öğretiminin Etkisi
}

\begin{abstract}
Giriş
Kavramlar, öğrenme sürecinin temeli olarak kabul edilmektedir. Bunlar ortak tepkiye yol açan uyaranlar takımıdır (Özyürek, 1983). Zihinsel yetersizliği olan bireylerin kavram öğrenme süreçleri, bireylerin hem akademik becerilerine temel oluşturmakta hem de çevrelerindeki nesneleri ve olayları anlayabilmelerine yardımcı olmaktadır (Vuran ve Çelik, 2013). Kavramlar zihinsel yetersizliği olan bireylerin akademik yaşantılarının yanı sıra günlük yaşam becerileri üzerinde de önemli bir yer tutmaktadır (Sucuoğlu, 2008).

Zihinsel yetersizliği olan bireylerin toplum içerisinde bağımsız yaşayabilmeleri için günlük yaşam becerilerini ve içerisinde kavramların da bulunduğu işlevsel akademik becerileri kazanmaları gerekmektedir. Günlük yaşam becerileri bireylerin, ev içinde ve dışında yaşamlarını bağımsız olarak sürdürebilmeleri ve kişisel bakım ihtiyaçlarını karşılayabilmeleri için gerekli olan tüm becerileri içermektedir (Varol, 2005). İşlevsel akademik beceriler ise, bireylerin toplumda bağımsız olarak yaşayabilmesi ve çalışabilmesi için gerekli olan becerilerdir (Çifci-Tekinarslan, 2015). Günlük yaşam becerilerinin öğretimi, aynı zamanda pek çok kavram ve diğer becerilerin kazandırılmasına yönelik etkinlik firsatı sağlamaktadır (Varol, 2005). Dolayısıyla günlük yaşam becerileri ile işlevsel akademik becerilerin öğretimine birlikte yer verilebileceği belirtilmektedir (Snell ve Brown, 2000). İki farklı becerinin birlikte öğretimine yönelik Collins, Karl, Riggs, Gallowey ve Hager (2010), altı basamaklı bir uygulama süreci önermektedir. Bu süreçte ilk olarak öğrencilerin gereksinimlerine göre öğretimsel amaçlar belirlenmekte, ikinci olarak bireyselleştirilmiş eğitim planına uygun öğretimsel bağlam planlanmaktadır. Üçüncü olarak kanıt temelli bir öğretim süreci seçilmektedir. Dördüncü olarak bu öğretim bağlamının içerisine hedeflenmeyen bilgi gömülmektedir. Ardından beşinci basamak olarak öğretim sürecine yönelik veri toplanmakta ve bu veriler grafikleştirilmektedir. Son olarak genelleme ve kalıcılık aşamaları için etkinlikler planlanmakta ve uygulanmaktadır.
\end{abstract}

Alanyazında zihinsel yetersizliği olan öğrencilerin devam ettiği ayrıştırılmış eğitim ortamlarında günlük yaşam becerilerinin ve kavram öğretimlerinin çoğunlukla ayrı ayrı yapıldığı görülmektedir (Karabulut ve Yıkmış, 2010; Birkan, 2002; Aslan ve Eratay, 2009). Buna karşın Browder, Wakeman, Flowers, Rickelman ve Pugalee (2007), yetersizliği olan öğrencilere, kavramların günlük yaşam becerileri içerisinde ve bu becerilerde kullanılan araçlarla sunulmasının daha etkili olabileceğini belirtmiştir. Doğal öğretim yaklaşımı da kavramların günlük yaşam becerileri içerisinde öğretilmesine olanak sağlamaktadır. Doğal öğretim, uygulamalı davranış analizi ilkelerinden yola çıkarak öğrencinin öğrenme ortamlarında etkileşime dayalı çevresel düzenlemeleri içeren bir yaklaşımdır (Pretti-Frontczak ve Bricker, 2004). Doğal öğretim yaklaşımında yer alan öğretim yöntemlerinden biri de gömülü öğretimdir. Gömülü öğretim, üzerinde uzlaşmaya varılan bir tanımı olmasa da, sınıf rutinleri içerisinde ayrık öğretim denemeleri şeklinde sunulan sistematik bir öğretim yöntemidir (Riesen, McDonnell, Johnson, Polychronis ve Risen 2002; Johnson, McDonnell, Holzwarth ve Hunter, 2004). Bu yöntemde, öğrencilerin öğretimsel hedefleri, sınıf içerisindeki günlük rutinlere, etkinliklere ve geçişlere gömülerek onlara gereksinimleri olan hedef davranış için öğrenme firsatı sağlanmaktadır (Aldemir-Fırat ve Ergenekon, 2018). Alanyazında kanıt temelli uygulamalar arasında gösterilen gömülü öğretimin birçok araştırma ile etkililiği ortaya konmuştur. Gömülü öğretimin, genellikle kaynaştırma ortamlarında gelişimsel yetersizliği olan öğrencilere yönelik kavram, beceri, dil, erken okuryazarlık ve sosyal beceri alanlarında sıklıkla kullanılan etkili bir yöntemdir (Simpson ve Keen, 2010; Jameson, McDonnell, Johnson, Riesen ve Polychronis, 2007; Wolery, Doyle, Gast ve Ault, 1993; Ducharme, Lucas ve Pontes, 1994; Pretti-Frontczak ve Bricker, 2001; Daugherty, Grisham-Brown ve Hemmeter, 2001; GrishamBrown, Shuster, Hemmeter ve Collins, 2000; Horn, Lieber, Sandall, Schwartz ve Li, 2000). Gömülü öğretimin farklı gelişim alanlarında etkili olmasının yanı sıra, farklı ortamlarda, farklı kişilerle ve farklı araç-gereçlerle kolaylıkla çalışılabilmesi nedeniyle öğrenilen becerilerin genellenebilirliğini artırmada fayda sağlamaktadır (Wolery, Anthony, Caldwell, Snyder ve Morgante, 2002).

Alanyazın incelendiğinde, gömülü öğretim yönteminin farklı yaş gruplarında, farklı eğitim ortamlarında ve farklı hedef davranışların öğretiminde kullanıldığı görülmektedir. Araştırmalarda gömülü öğretim yönteminin özellikle yetersizliği olan öğrencilerin eğitim gördüğü kaynaştırma ortamlarında etkili olduğu ortaya konmakla birlikte, yapılan çalışmaların okul öncesi kaynaştırma ortamlarında yoğunlaştığı görülmektedir (Aldemir-Fırat ve 
Ergenekon, 2018). Bunun yanı sıra orta ve ağır yetersizliğe sahip öğrencilere yönelik kavramların, günlük yaşam etkinliklerinin içerisine gömülerek uygulandığı araştırmalar da bulunmaktadır. Bu araştırmalardan, Collins, Hager ve Galloway (2011), orta derecede zihinsel yetersizliği olan üç ortaokul öğrencisine, sabit bekleme süreli ipucu işlem sürecini kullanarak iki uygulamayı birlikte ele almıştır. Sınıf öğretmeni, sınıf düzeyindeki programda yer alan konuları öğrencilere öğretirken, özel eğitim öğretmeni öğretilen konuları öğrencilerin günlük yaşamlarıyla ilişkilendirerek etkinlikler içerisinde sunmuştur. Bu kapsamda dil etkinliği ile işlevsel okuma becerileri, pişirme etkinliği ile fen bilgisinde maddenin halleri konusu ve alışveriş etkinliği ile hesaplama becerileri birlikte ele alınmıştır. Araştırma sonucunda öğretimsel hedeflerin işlevsel etkinliklerle birlikte ele alınmasının öğrencilerde edinim, kalıcılık ve genelleme sağladığı görülmektedir. Karl, Collins, Hager ve Ault (2013), orta düzeyde zihinsel yetersizliği olan dört ortaokul öğrencisine yönelik eş zamanlı ipucu işlem sürecini kullanarak işlevsel bir etkinlik içerisinde akademik bir beceri öğretmeyi amaçlamıştır. Bu çalışmada yemek pişirme etkinliği içerisine Türkçe için yaş düzeyine uygun okuma, matematik için yüzde problemleri çözme ve fen için kuvvet konuları gömülmüştür. Araştırma sonucunda, tüm katılımcıların yemek pişirme etkinliği içerisinde hedeflenen akademik becerileri edindiği görülmüştür. Collins, Evans, Galloway, Karl ve Miller (2007) tarafindan yapılan araştırmada orta ve ağır derecede zihinsel yetersizliği olan öğrencilere işlevsel okuma becerileri üç farklı yöntem kullanılarak öğretilmiştir. $\mathrm{Bu}$ yöntemler, kaynak odada sunulan yoğunlaştırılmış doğrudan öğretim (direct massed trial instruction), genel eğitim sınıfında sunulan doğrudan ayrık denemelerle öğretim (direct distributed trial instruction) ve ayrık denemelerle sunulan gömülü öğretimdir (embedded distributed trial instruction). Araştırma bulgularında orta ve ağır derecede zihinsel yetersizliği olan öğrencilerin hedef becerileri öğrendiği görülmüştür. Ayrıca üç yöntemde de becerilerin edinimi ve kalıcılığı, genel ve özel eğitim sınıflarına göre çok az farklılaşma göstermiştir.

Yapılan araştırmalara bakıldığında ele alınan hedef becerilerin matematik, fen ve Türkçe gibi alanlarda olduğu ve bunların günlük yaşam becerilerinin içerisine gömülerek, kaynaştırma eğitim ortamlarında sunulduğu görülmektedir. Ancak sınırlı sayıda araştırma, ayrıştırılmış eğitim ortamlarında kavramların günlük yaşam becerilerinin içerisine gömülerek öğretilebildiğini ortaya koymaktadır. Ülkemizde Özel Eğitim Uygulama okullarına devam eden öğrencilerin eğitim-öğretim programlarında öz bakım ve günlük yaşam becerilerinin öğretimine ağırlık verildiği bilinmektedir. Günlük yaşam becerilerinin içerisinde de birçok işlevsel akademik becerinin yer aldığı göz önünde bulundurulduğunda, bu becerilerin günlük yaşam becerilerinin içerisine gömülerek öğretilmesinin verimli olacağı düşünülmektedir. Beceri materyallerinin ortak kullanılabilmesi, aynı anda hem günlük yaşam becerisinin hem de işlevsel akademik becerinin çalışılabiliyor olması hem öğretmene zaman kazandırması hem de öğrenciye birden fazla amacın öğretimine firsat sağlaması açısından önemlidir. Karl, Collins, Hager ve Ault, (2013) maliyet ve zaman açısından verimliliği göz önünde bulundurulduğunda, kavramların günlük yaşam becerilerinin içerisine gömülerek öğretilmesinin oldukça önemli olduğunu belirtmektedir. Tüm bunlardan hareketle, yetersizlikten etkilenmiş ögrencilerin eğitiminde kullanılan gömülü öğretim yönteminin, farklı eğitim ortamlarında, farklı kişilerle de çalışılarak etkililiğinin ve verimliliğinin ortaya konmasının, hem alanyazına hem de eğitimcilere katkısının olacağı düşünülmektedir. Bu doğrultuda araştırmanın amac1, ayrıştırılmış eğitim ortamında bulunan zihinsel yetersizliği olan öğrencilere, günlük yaşam becerisi içerisine gömülerek sunulan işlevsel akademik beceri öğretiminin, öğrencilerin bu becerileri kazanmalarına olan etkisini incelemektir.

Yöntem

\section{Araştırmanın Deseni}

Bu araştırmada, tek denekli deneysel desenlerden denekler arası yoklama evreli çoklu yoklama modeli kullanılmıştır (Tawney ve Gast, 1984). Bu model bir bağımsız değişkenin etkililiğinin üç farklı katılımcı üzerinde incelendiği modeldir. Tüm katılımcılarda eş zamanlı olarak başlama düzeyi verisi toplanmakta ve kararlı veri elde edildikten sonra birinci katılımcı ile uygulamaya başlanmaktadır. Birinci katılımcıda hedeflenen ölçüt karşılandığında tüm katılımcılarda yoklama evresi tekrarlanır ve ikinci katılımcı ile uygulamaya başlanır. İkinci katılımcıda hedeflenen ölçüt karşılandığında tüm katılımcılarda yoklama evresi tekrarlanır ve üçüncü katılımcı ile uygulamaya başlanır. Üçüncü katılımcıda hedeflenen ölçüt karşılandığında tüm katılımcılarda yoklama evresi tekrarlanır. (Tekin-İftar, 2018).

\section{Katılımcılar ve Seçimi}

Araştırmanın katılımcılarını 2015-2016 öğretim yılında Ankara ilinde bulunan özel eğitim ve iş uygulama merkezine devam eden zihinsel yetersizliği olan birisi erkek, ikisi kız toplam üç öğrenci oluşturmaktadır. 
Katılımcıların belirlenmesinde öğrencilerin; a) hafif ve orta derecede zihinsel yetersizlik tanısının olması, b) zihinsel yetersizlik dışında ek engelinin bulunmaması, c) çalışmaya katılmak için istekli olması ve ebeveynleri tarafından çalışmaya katılmaları için onay verilmiş olması, d) bağımsız olarak bıçakla kesebilmesi, e) yarım kavramına ve sandviç yapma becerisine sahip olmaması ve bunlara yönelik herhangi bir sistematik öğretim yapılmamış olması, f) iki basamaklı yönergeleri yerine getirmesi ve g) taklit etme becerisine sahip olması dikkate alınmıştır.

Katılımcıların seçiminde, ilk olarak öğrencilerin sınıf öğretmenleri ile görüşülmüş ve raporları incelenmiştir. Ölçütleri karşıladığı düşünülen öğrencilere matematik kavramlarını ve günlük yaşam becerilerini içeren kontrol listeleri uygulanmıştır. Uygulanan kontrol listeleri sonucunda çalışmaya yarım kavramına ve sandviç yapma becerisine sahip olmayan üç öğrenci çalışmaya dâhil edilmiştir.

Tablo 1. Katılımcıların Demografik Özellikleri

\begin{tabular}{ccccc}
\hline Katılımc & Cinsiyet & Yaş & Tanı & Eğitim süresi \\
\hline 1 & $\mathrm{~K}$ & 15 & Orta MR & 8 \\
2 & $\mathrm{E}$ & 11 & Hafif MR & 4 \\
3 & $\mathrm{~K}$ & 13 & Orta MR & 5 \\
\hline
\end{tabular}

Tablo 1'de görüldüğü üzere, birinci katılımcı, 15 yaşında, IQ puanı 45-49 aralığında, orta MR tanısına sahip, \%70 özürlü raporu bulunan bir kız öğrencidir. İkinci katılımcı, 11 yaşında, hafif MR tanısına sahip bir erkek öğrencidir. Üçüncü katılımcı, 13 yaşında, IQ puanı 35-40 aralığında, orta MR tanısına sahip, \%70 özürlü raporu bulunan bir kız öğrencidir. Katılımcıların özel eğitim uygulama okula devam etme süreleri dört ile sekiz yıl arasında değişmektedir.

\section{Bağımlı Değişken}

$\mathrm{Bu}$ araştırmanın bağımlı değişkeni, zihinsel yetersizliği olan öğrencilerin yarım kavramındaki ve sandviç yapma becerisindeki performans düzeyleridir. Öğrenciler yarım kavramını diğer kavramlardan (bütün, çeyrek) ayırt edememekte olup, sandviç yapma becerisinde ise tüm malzemeleri gösterebilmekte, fakat "sandviç yap" yönergesi verildiğinde beceri basamaklarını bağımsız olarak gerçekleştirememektedir.

\section{Bağımsız Değişken}

Günlük yaşam becerilerinden sandviç yapma becerisinin içerisine yarım kavramının gömülerek öğretilmesi bu araştırmanın bağımsız değişkenidir. Bu öğretim sürecinde gömülü öğretim model olma ipucuyla birlikte sunulmuştur.

\section{Araştırma Ekibi}

Araştırmanın başlama düzeyi, uygulama ve yoklama oturumları zihin engellilerin eğitimi bölümü 4.sınıf öğrencileri tarafından yürütülmüştür. Bu öğrenciler öğretmenlik uygulaması dersi kapsamında özel eğitim ve iş uygulama merkezinde öğretmen adayı olarak staj yapmaktadır. Öğretmen adaylarının tümü lisans derslerinde zihin engellilere beceri ve kavram öğretimi dersini almış ve bu derste gömülü öğretim yöntemine ilişkin teorik bilgi edinmişlerdir. Ancak uygulamaya dönük bir deneyimleri yoktur. Uygulama öncesi araştırmacılar tarafindan öğretmen adaylarına gömülü öğretime ilişkin bilgilerini tekrar edebilecekleri bir eğitim verilmiştir. Teorik eğitim iki gün ard arda üçer saat, uygulamalı eğitim haftada iki gün toplamda üç oturum sürmüştür. Bu eğitimde öncelikle öğretmen adaylarına ders notlarına ek olarak gömülü öğretim uygulamalarını içeren makaleler verilmiş ve adaylarla birlikte makalelerin içerikleri tartışılmıştır. Böylece adayların gömülü öğretime ilişkin teorik bilgileri tekrar edilmiştir. Ardından gömülü öğretime ilişkin örnek uygulama videoları izlettirilerek, videolar üzerinden uygulamaya ilişkin açıklamalar yapılmıştır. Ardından öğretmen adaylarına ön uygulama yapmak amacıyla katılımcılardan farklı bir öğrenci ile uygulama yaptırılmış ve bu uygulama tüm öğretmen adayları tarafindan 
izlenmiştir. $\mathrm{Bu}$ süreçte uygulama öğretim elemanları tarafindan anında ve düzeltici dönütlerle öğretmen adaylarının uygulamalarına yönelik düzeltmeler yapılmıştır. Öğretmen adayları, gömülü öğretim uygulamasında düzeltmeye ve dönüte gerek duymadan öğretim sürecini yürütür hale geldiklerinde araştırmanın uygulama sürecine geçilmiştir.

Araştırmanın izleme oturumları ise araştırmanın birinci, ikinci ve üçüncü yazarları olan öğretmenlik uygulamasını yürüten öğretim elemanları tarafından gerçekleştirilmiştir. Öğretim elemanlarının öğretmenlik deneyimleri olmakla birlikte; en az 2 yıllık öğretmenlik uygulaması yürütücülüğü ve gömülü öğretime ilişkin uygulama deneyimleri bulunmaktadır. Araştırmanın güvenirlik verileri, zihin engellilerin eğitimi bölümünde yüksek lisans yapan, öğretmenlik uygulamasını yürüten ve gömülü öğretime ilişkin uygulama deneyimi bulunan bağımsız bir araştırmacı tarafından yapılmıştır. Güvenirlik verileri analiz edilmeden önce, gözlemciye, güvenirliği nasıl yapacağına ilişkin eğitim verilmiştir.

\section{Ortam, Zaman ve Materyaller}

$\mathrm{Bu}$ araştırma birebir olarak katılımcıların devam ettiği özel eğitim ve iş uygulama okulunda bulunan çalışma odasında ve okulun mutfağında gerçekleştirilmiştir. Uygulama sürecinde öğretmen adayıyla katılımcı birebir çalışmıştır. Bireysel oda yaklaşık olarak 12 metrekare iken mutfak yaklaşık 25 metrekaredir. Çalışma odasında katılımcıların boyuna uygun bir masa ve öğretmen adayı ile katılımcının oturması için iki sandalye ve materyallerin konulması için bir sehpa bulunmaktadır. Mutfakta ise bir firın, bir buzdolabı, bir masa, sekiz sandalye, bir tezgâh, mutfak dolapları ve mutfak araç gereçleri bulunmaktadır.

Katılımcılara sandviç yapma becerisinin içerisine gömülerek yarım kavramının kazandırılmasının amaçlandığı uygulama oturumları okulun mutfağında yapılmış olup, katılımcılarla haftada iki gün ve günde bir oturum çalışılmıştır. Uygulama oturumları 30 dakika sürmüştür. Yarım kavramına ilişkin yoklama oturumları bireysel çalışma odasında yapılmış ve 10 dakika sürmüştür. Sandviç yapma becerisine ilişkin yoklama oturumları mutfakta gerçekleştirilmiş olup 30 dakika sürmüştür.

Araştırmada uygulama oturumlarında gerçek nesneler kullanılırken, yoklama oturumlarında gerçek nesneler ve gerçek nesne resimleri kullanılmıştır. Uygulama oturumlarında gerçek nesne olarak, sandviç malzemelerinden ekmek, domates, salatalık, marul, dilimlenmiş kaşar peyniri ve salam kullanılmıştır.

\section{Veri Toplama Araçları}

Araştırmada kullanılan veri toplama araçları, başlama düzeyi ve yoklama oturumlarında yarım kavramı için yarım kavramına yönelik ölçüt bağımlı ölçü aracı (ÖBÖA) ve sandviç yapma becerisi için sandviç yapma becerisi ÖBÖA'dır. Yarım kavramına yönelik ÖBÖA altı bildirimden oluşmaktadır. Bu ÖBÖA'nın ilk sütununda kavramın ilişkisiz niteliklerinin yer aldığ 1 bildirimler, ikinci sütununda hedef davranışın kabul edilen doğruluk yüzdesinin yer aldığı ölçüt, üçüncü sütununda her bir bildirimi ölçmeye yönelik sorular ve son sütununda öğrenci tepkilerinin kayıt edildiği kayıt sütunu bulunmaktadır. Katılımcıların kavramı edinme ölçütü sorulan dört sorudan üçünü doğru yanıtlaması olarak belirlenmiştir.

Sandviç yapma becerisinin basamakları beceriyi yapabilen birini gözleyerek basamakların analiz edilmesi ve sıralanmasıyla oluşturulmuştur. Hazırlanan beceri analizine ilişkin iki özel eğitim uzmanından görüş alınmış ve bu görüşler doğrultusunda beceri analizine son şekli verilmiştir. Sandviç yapma becerisi ÖBÖA onaltı basamaktan oluşmuştur. Analizin basamakları sandviç yapma becerisi ÖBÖA’nın bildirimler sütununa yazılmış olup, hedef davranışın kabul edilen doğruluk yüzdesi ölçüt sütununda, becerinin yapılmasına ilişkin ana yönerge sorular sütununda ve öğrenci tepkileri kayıt sütununda yer almaktadır. Katılımcıların beceriyi gerçekleştirme ölçütü tüm beceri basamaklarını bağımsız olarak yapması olarak belirlenmiştir.

\section{Uygulama Süreci}

Araştırmanın uygulama süreci, toplu yoklama, uygulama, izleme ve genelleme oturumlarından oluşmuştur. Her bir oturumun nasıl uygulandığı aşağıda ayrıntılı olarak açıklanmıştır.

\section{Toplu Yoklama Oturumlart}

$\mathrm{Bu}$ araştırmada, yarım kavramına ve sandviç yapma becerisine ilişkin toplu yoklama oturumları her bir katılımcı için uygulama öncesi ve sonrasında toplanmıştır. Toplu yoklama oturumlarının her birinde, yarım kavramı ölçüt bağımlı ölçü aracı ve sandviç yapma becerisi ölçüt bağımlı ölçü aracında bulunan gerçek nesneler 
ve gerçek nesne resimleri kullanılmıştır. Yarım kavramı ölçüt bağımlı ölçü aracında 3/4 ölçüt olarak kabul edilmiştir. Sandviç yapma becerisi için ise her bir beceri basamağını gerçekleştirme düzeyi belirlenmiştir.

Toplu yoklama oturumları katılımcılar ile birebir olarak gerçekleştirilmiştir. Bu oturumlar sırasında katılımcıların tüm yanıtlarına tepkisiz kalınmıştır. Benzer işlem süreçleri uygulanarak tüm katılımcılar için toplu yoklama oturumları gerçekleştirilmiştir.

\section{Uygulama Oturumlart}

Model ipucunun kullanıldığı gömülü öğretim oturumlarında, uygulamacı tarafından öğrencinin yarım kavramına yönelik bilgisini sergilemesi için gereksinim oluşturulmuş ve çalışmaya dikkat çekilmiştir. Örneğin; öğretmen adayı sabah ilk derste katılımcıya; "Sabah erkenden okula geldik, kahvaltımızı yapmamış olabiliriz, benim karnım çok aç, peki ya senin?” gibi etkileşimler kurarak gereksinim oluşturmuştur. "O halde bu derste karnımızı doyuralım, bakalım yiyecek neler var?” diyerek malzemeler incelenmiştir. Öğretmen adayı buzdolabındaki malzemeleri göstererek "Sanırım buradaki malzemelerle sandviç yapabiliriz, ben çok severim sandviçi, sen de sever misin? Haydi, hazırsan sandviç yapmaya başlayalım” diyerek uygulamaya giriş yapmıştır. Uygulama sırasında öğretmen adayı beceri basamaklarına model olarak katılımcının beceri basamağını yapmasını istemiştir. Örneğin; öğretmen adayı katılımcıya "Şimdi beni dikkatlice izle. Kesme tahtası, tabak, bıçak ve peçeteyi tezgâha koyuyorum. Şimdi sen de benim yaptığımın aynısını yap." demiştir. Öğretmen adayı bir yandan beceri basamaklarına model olurken, bir yandan da yarım kavramını öğretmeye uygun olan beceri basamaklarına geldiğinde, beceri basamağının içerisine gömülmüş olan yarım kavramının ilişkili niteliklerine dikkat çekerek sunumunu yapmıştır. Örneğin; öğretmen adayı ekmeklerin içinden bir bütün ekmeği alarak "Aaa burada bütün ekmek varmış. Bütün ekmek bir kişiye fazla olur. Bütün ekmeğin yarısı ile sandviç yaparsak daha iyi olur. Şimdi bütün ekmeği bıçakla ortasından ikiye kesiyorum." diyerek ekmeği ortadan ikiye kesmiştir. "Bak burada iki tane yarım ekmeğimiz oldu. Biz yarım ekmekle sandviç yapacağız. Bak bu yarım ekmek. Haydi, sen de benim gibi yap." diyerek bir yandan beceri basamağını öğretirken bir yandan da kavramın sunumunu yapmıştır.

Böylece hem yarım kavramının olumlu ve olumsuz örneklerine hem de beceri basamağının yapılışına model olmuştur. Öğretmen adayının sunduğu model ipucunun ardından katılımcının verdiği olumlu tepkiler ayrıntılı şekilde betimlenerek pekiştirilmiştir. Katılımcının verdiği olumsuz tepkiler için ise beceri basamağına model olunarak katılımcıdan beceri basamağını tekrar yapması istenmiştir. Katılımcının tepkisiz kaldığı durumlarda öğretmen adayı yönergeyi tekrar etmiş ve katılımcı yine yapamazsa model olma ipucu kullanmıştır. Her bir öğretim basamağı için öğretim sunumu bu şekilde tekrar edilmiştir.

Uygulama oturumlarının ardından, yarım kavramına ve sandviç yapma becerisine ilişkin öğretim sonu değerlendirme oturumları düzenlenmiştir. $\mathrm{Bu}$ oturumlarda, yarım kavramının değerlendirilmesinde, sandviç yapma becerisinde kullanılan malzemelerin resimleri kullanılarak verdikleri yanıtlar kayıt edilmiştir. Sandviç yapma becerisi için ise her bir beceri basamağını gerçekleştirme düzeyi belirlenmiştir. Bu oturumlar katılımcılar ile birebir olarak gerçekleştirilmiştir.

\section{İzleme Oturumlart}

Uygulama oturumları bittikten sonra, yarım kavramı ve sandviç yapma becerisi ile ilgili öğrencilerin öğrendiklerini ne düzeyde sürdürdüklerini belirlemek amacıyla izleme oturumları düzenlenmiştir. Bu oturumlar, uygulama oturumları sona erdikten 4 ve 6 hafta sonra uygulama oturumlarının yapıldığ öğretim kurumunda, toplu yoklama oturumlarının yürütüldüğü şekilde gerçekleştirilmiştir.

\section{Güvenirlik Analizi}

Araştırmada güvenirlik verileri, gözlemciler arası güvenirlik ve uygulama güvenirliği olmak üzere iki farklı şekilde toplanmıştır. Gözlemciler arası güvenirlik ve uygulama güvenirliği her bir katılımcı için toplu yoklama, uygulama, izleme ve genelleme oturumlarının \%30’unda yansız atama sonucu kayıtlar izlenerek toplanmıştır.

\section{Gözlemciler Arası Güvenirlik}

Güvenirlik verileri, araştırmacılardan biri ve araştırmaya dâhil olmayan bağımsız bir araştırmacı tarafından değerlendirilerek kodlanmıştır. Kodlama öncesinde, araştırmacıya hem kavramın hem de sandviç yapma 
becerisinin ölçüt bağımlı ölçü aracı tanıtılarak bir video üzerinden kodlama yapılmıştır. Daha sonra uygulama videolarının \% 30’u verilerek gözlemciler arası güvenirlik verilerinin analiz edilmesi istenmiştir. Araştırmanın verileri katılımcıların hedef davranışları sergileyip sergilememe durumlarına göre ölçü araçlarına "+” ve "_" şeklinde kaydedilmiştir. Araștırmada gözlemciler arası güvenirlik; "görüş birliği/(görüş birliği+görüş ayrılığ1)x100" formülü kullanılarak hesaplanmıştır. (Tekin ve Kırcaali-İftar, 2001). Birinci katılımcının yarım kavramı ve sandviç yapma becerisi için gözlemciler arası güvenirlik yüzde ortalaması \% 91, ikinci katılımcının \% 93 ve üçüncü katılımcının ise \% 96 olarak belirlenmiştir.

\section{Uygulama Güvenirliği}

Araştırmada öğretim sürecinin planlandığı şekilde yürütülüp yürütülmediğini belirlemek amacıyla uygulama güvenirliği verileri toplanmıştır. Uygulama güvenirliğini hesaplamak için uygulama adımlarını ve uygulamacı davranışlarını içeren uygulama güvenirliği veri kayıt formu hazırlanmıștır. Bu form bağımsız araştırmacıya verilmiş ve örnek bir video izlenerek, birlikte uygulama formu doldurulmuştur. Ardından bağımsız olarak değerlendirme yapması için örnek bir video verilmiş ve bağımsız araştırmacının formu doldurması istenmiştir. Veriler \% 80 düzeyinde bağımsız olarak tutarlı hale geldiğinde gözlemciye gerçek uygulama videolarının \%30'u verilerek uygulama güvenirliği verilerini analiz etmesi istenmiștir. Uygulamacının gerçekleștirdiği basamaklara “+”, gerçekleştirmediği basamaklara “-” verilerek veri kayıt tablosuna işaretlenmiştir. Araştırmanın uygulama güvenirliği "gözlenen uygulamacı davranışı/planlanan uygulamacı davranışı X 100" formülü kullanılarak hesaplanmıştır (Tekin ve Kırcaali-İftar, 2001). Uygulamanın güvenirlik verileri \% 100 olarak bulunmuştur.

\section{Sosyal Geçerlik}

$\mathrm{Bu}$ araştırmanın sosyal geçerlik verileri, araştırmanın uygulama sürecini gerçekleştiren öğretmen adayları ile görüşme yapılarak toplanmıştır. Sandviç yapma becerisinin içerisine gömülerek sunulan yarım kavramının öğretimine ilişkin öğretmen adaylarına; a) Gömülü öğretim yöntemi hakkında ne düşünüyorsunuz? ve b) Günlük yaşam becerisi ile yarım kavramının birlikte öğretilmesine ilişkin görüşleriniz nedir? soruları sorulmuştur. Öğretmen adayları gömülü öğretim yaklaşımının öğretim sürecinin esnek ve kolay uygulanabilir olduğunu ve doğal bir sunum ortamı sağladığını belirtmişlerdir. Ayrıca günlük yaşam becerisi ile kavramın birlikte sunulmasının etkili ve kullanışlı olduğunu; ek olarak uygun olabilecek çeşitli günlük yaşam becerileri ile kavramların birlikte sunulmasının zaman ve maliyet açısından verimli olabileceğini ifade etmişlerdir.

\section{Verilerin Analizi}

Araştırma sonunda elde edilen veriler, grafiksel analiz yoluyla analiz edilmiştir. Araştırmanın grafiklerinde Y ekseni bağımlı değişkenin nicel olarak ifade edildiği, sandviç yapma becerisi veya yarım kavramı doğru tepki yüzdelerinin yer aldığı eksendir. X ekseni ise grafikte oturumları gösteren eksendir. Her bir oturumda yapılan uygulama sonucunda elde edilen veriler nicelleştirilerek grafiğe işlenmiştir. $\mathrm{Bu}$ doğrultuda $\mathrm{X}$ ekseninin $\mathrm{Y}$ ekseninden uzaklaşması görsel olarak bağımsız değişkenin bağımlı değişken üzerindeki etkisini ortaya koymaktadır (Tekin-İftar, 2018).

\section{Bulgular}

Bu araştırmada sandviç yapma becerisinin içerisine gömülerek öğretilen yarım kavramının, zihinsel yetersizliği olan ögrencilerin bu kavramı ve beceriyi kazanmasına olan etkisi incelenmiştir. Bu araştırmanın bulguları Grafik 1 ve Grafik 2'de gösterilmiştir. 


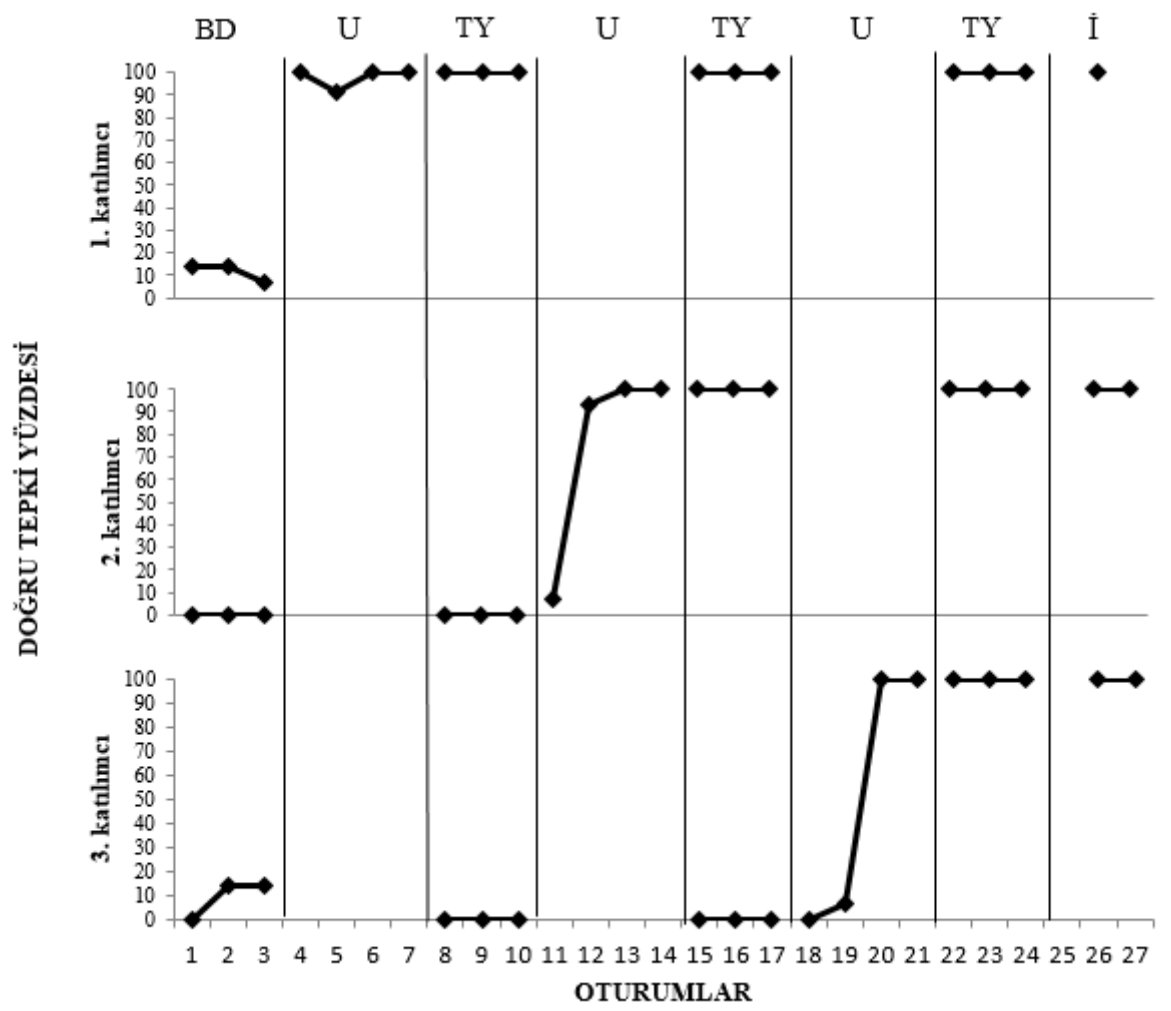

Grafik 1. Katılımcıların sandviç yapma becerisini gerçekleştirme yüzdeleri

Grafik 1'de görüldüğü gibi, çalışmaya katılan üç katılımcı başlama düzeyinde sandviç yapma becerisini bağımsız olarak gerçekleştirememiştir. Uygulama süreci sonunda her üç katılımcının beceriyi gerçekleştirme düzeyinin \%100 olduğu görülmektedir. Üç öğrenci de dört oturum sonunda sandviç yapma becerisi ile ilgili ölçütü sağlamışlardır. Birinci katılımcının uygulama sona erdikten dört hafta sonra gerçekleştirilen izleme oturumunda sandviç yapma becerisi gerçekleştirme düzeyinin \%100 olduğu görülmektedir. Bu katılımcı okula devamsızlığı nedeniyle ikinci izleme oturumuna katılamamıştır. İkinci ve üçüncü katılımcıların uygulama sona erdikten dört ve altı hafta sonra gerçekleştirilen izleme oturumlarında, sandviç yapma becerisi gerçekleştirme düzeylerinin \%100 olduğu görülmektedir. Bu sonuçlar, tüm katılımcıların model olma ipucuyla sunulan sandviç yapma becerisini öğretimi sona erdikten sonra da beceriyi gerçekleştirme düzeylerini sürdürdüklerini göstermektedir. 


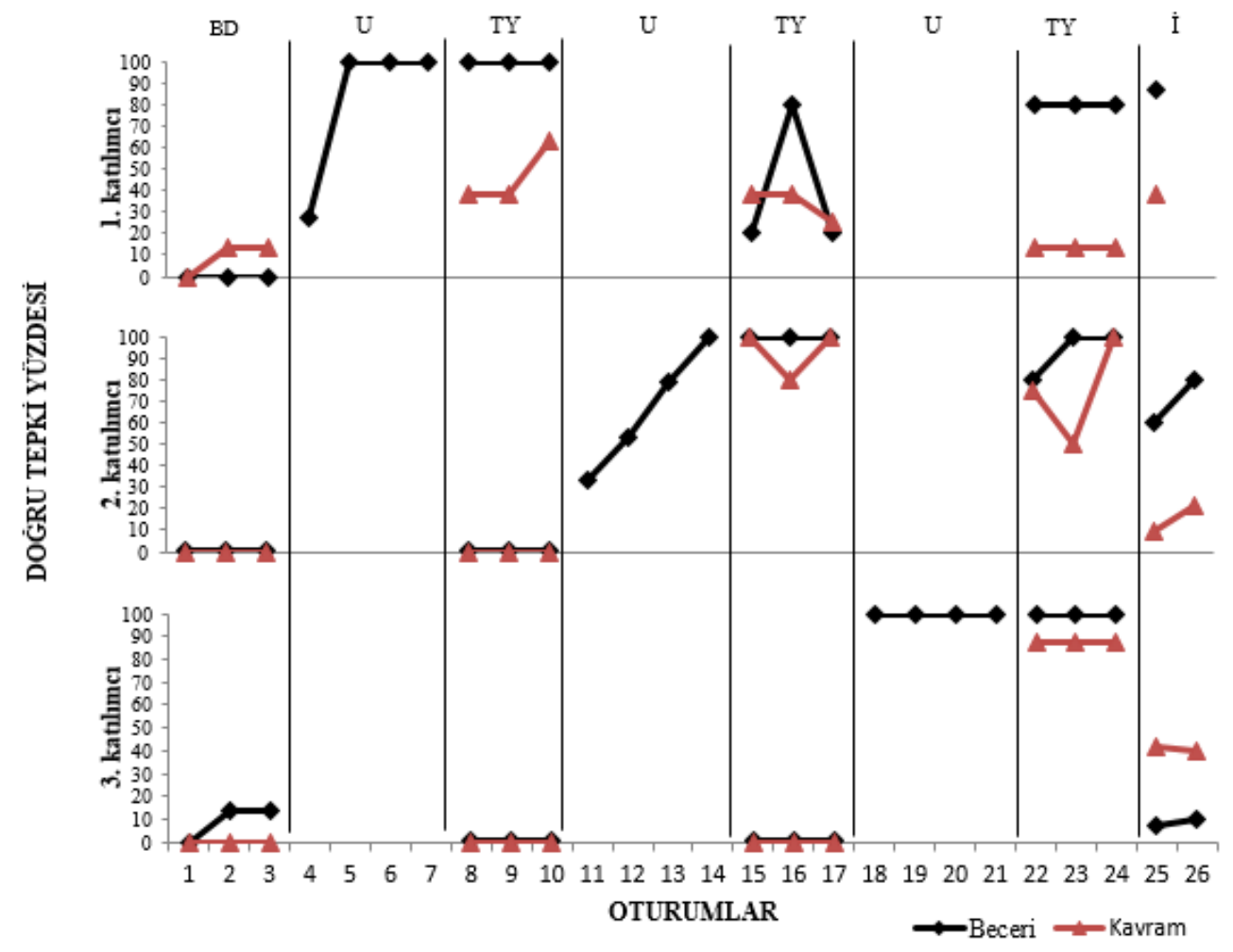

Grafik 2. Katılımcıların sandviç yapma becerisinin içerisine gömülerek öğretilen yarım kavramını beceride kullanılan malzemeler ve kavram ölçüt bağımlı ölçü aracı için hazırlanan malzemelerle gerçekleştirme yüzdeleri

Grafik 2'de görüldüğü gibi, tüm katılımcıların başlama düzeyinde yarım kavramı ÖBÖA'da yer alan davranışları bağımsız olarak gerçekleştiremediği görülmektedir. Tüm katılımcıların beceri malzemelerinden oluşan materyallerle yapılan öğretim sonu değerlendirme oturumlarında (beceri $-\boldsymbol{H}$ ) yarım kavramı ÖBÖA'da yer alan davranışları gerçekleştirme düzeyinin $\% 100$ olduğu görülmektedir. Ancak son yapılan toplu yoklama oturumuna bakıldığında birinci ve ikinci katılımcının beceri malzemelerinden oluşan materyallerde yarım kavramını gerçekleştirme düzeyinin $\% 80$, üçüncü katılımcının ise $\% 100$ düzeyinde performans sergilediği görülmüştür. Ancak toplu yoklama oturumları (kavram - ) incelendiğinde, kavram ÖBÖA'ya göre hazırlanan materyallerle, birinci katılımcının yarım kavramını gerçekleştirme düzeyi ortalama \%10, ikinci katılımcının ortalama $\% 75$ ve üçüncü katılımcının ortalama $\% 90$ düzeyinde olduğu görülmektedir. Bu sonuçlar iki öğrencinin yarım kavramını edinim düzeyinde kazandığını, ancak bir öğrencinin kavramı kazanamadığını göstermektedir.

İzleme oturumlarına bakıldığında, birinci katılımcının uygulama sona erdikten dört hafta sonra, sandviç malzemelerini içeren materyallerde yarım kavramını gerçekleştirme düzeyinin $\% 100$ olduğu, kavram ÖBÖA'ya göre hazırlanan materyallerde yarım kavramını gerçekleştirme düzeyinin $\% 40$ olduğu görülmektedir. Bu katılımcının okula devamsızlığı nedeniyle ikinci izleme oturumu gerçekleştirilememiş̧ir. İkinci katılımcının uygulama sona erdikten dört ve altı hafta sonra gerçekleştirilen izleme oturumlarında, sandviç malzemelerini içeren materyallerde yarım kavramını gerçekleştirme düzeyinin \%80 olduğu, kavram ÖBÖA'ya göre hazırlanan materyallerde yarım kavramını gerçekleştirme düzeyinin \%20 olduğu görülmektedir. Üçüncü katılımcının uygulama sona erdikten dört ve altı hafta sonra gerçekleştirilen izleme oturumlarında, sandviç malzemelerini içeren materyallerde yarım kavramını gerçekleştirme düzeyinin \%10 olduğu, kavram ÖBÖA'ya göre hazırlanan materyallerde yarım kavramını gerçekleştirme düzeyinin $\% 40$ olduğu görülmektedir. İzleme oturumlarında hem beceri öğretiminin yapıldığı malzemelerle hem de kavramın genel değerlendirmesine yönelik materyallerden oluşan ölçüt bağımlı ölçü araçlarıyla yoklama alınmıştır. Öğretim yapılan materyallerde birinci ve ikinci katılımcının kavramı sürdürdüğü görülürken, üçüncü katılımcının öğretim sonunda eriştiği düzeyi 
koruyamadığı; kavram ÖBÖA'daki materyallerde ise katılımcılardan hiçbirinin kavramı sürdüremediği görülmektedir.

\section{Tartışma ve Sonuç}

Bu araştırmada, ayrıştırılmış eğitim ortamında (özel eğitim ve iş uygulama merkezine) devam eden üç zihinsel yetersizliği olan öğrenciye yarım kavramının sandviç yapma becerisinin içerisine gömülerek öğretilmesinin, öğrencilerin beceriyi ve yarım kavramını öğrenmeleri üzerindeki etkisi incelenmiştir. Araştırmanın birkaç önemli sonucu olduğu düşünülmektedir. İlk olarak, araştırma bulguları incelendiğinde üç katılımcının sandviç yapma becerisini edindikleri ve bu becerinin kalıcılığının sağlandığı görülmüştür. Bununla birlikte, üç katılımcının sandviç yapma becerisinin içine gömülerek sunulan yarım kavramını, beceri öğretiminde kullanılan materyallerde edindiği görülmüştür. Bu bulgular günlük yaşam becerilerinden sandviç yapma becerisinin içerisine işlevsel akademik beceri olan yarım kavramının gömülerek öğretiminin hem sandviç yapma becerisinde hem de yarım kavramının kazanılmasında etkili olduğunu ortaya koymakta ve bu durum alanyazındaki araştırma sonuçları ile benzerlik göstermektedir (Collins, Evans, Galloway, Karl ve Miller, 2007; Collins, Hager ve Galloway, 2011; Jameson, McDonnell, Johnson, Riesen ve Polychronis, 2007; Johnson, McDonnell, Holzworth ve Hunter, 2004; Karl, Collins, Hager ve Ault, 2013).

İkinci olarak, tüm katılımcıların beceri öğretimindeki materyallerde kavramı edinmelerine rağmen, kavram ÖBÖA ile yapılan değerlendirmelerde sergiledikleri farklı sonuçlar dikkat çekicidir. İkinci ve üçüncü katılımcının sandviç yapma becerisinin içerisine gömülerek sunulan yarım kavramını, kavram ölçü aracındaki materyallerde edindiği, ancak birinci katılımcının yarım kavramını edinim düzeyinin \%10 düzeyinde kaldığı görülmektedir. $\mathrm{Bu}$ durum, üç katılımcının beceri öğretiminin yapıldığı materyaller ile yarım kavramını kazanmalarına rağmen, bu kavramı farklı materyallere genelleyemediklerini ortaya koymuştur. Bunun bir nedeninin, yarım kavramının sadece bir beceri içerisinde sunulması ve öğretim oturumlarında materyallerin çeşitlendirilmemesi olduğu söylenebilir. Bir diğer neden ise, uygulama sürecinin öğretim yılının sonuna denk gelmesi ve bu nedenle öğretim oturumları sayısının artırılamamasıdır. İzleme oturumlarında tüm katılımcıların sandviç yapma becerisini sürdürdükleri görülmüştür. Bu durumun özellikle becerinin sabah saatlerinde çalışlarak katılımcılar için doğal bir pekiştireç olmasından ve bir günlük yaşam becerisi olarak katılımcıları motive etmesinden kaynaklandığı düşünülmektedir.

Tüm bu bulgular özel eğitim uygulama okullarında eğitim alan öğrencilerin özellikleri ve mevcut durumları kapsamında ele alındığında; gömülü öğretim ile günlük yaşam ve işlevsel akademik becerilerin birlikte öğretilmesinin öğretmenlere örnek olabileceği ve alanyazına önemli katkı sağlayabileceği düşünülmektedir. Ulusal alanyazında gömülü öğretimle ilgili yapılmış araştırmaların sınırlı sayıda olduğu ve bu araştırmalarda gömülü öğretimin etkinlikler içerisinde planlandığı görülmektedir (Altun-Könez, Çelik, Yılmaz, Apaydın ve Aykut, 2015; Berkeban, 2013; Eren, Deniz ve Düzkantar, 2013; Odluyurt, 2010; Odluyurt, 2011; Kurt ve Tekin-İftar, 2008; Rakap ve Balikci, 2016; Şahin, 2015). Bu araştırma ise, ayrıştııılmış eğitim ortamında kavramın günlük yaşam becerisinin içerisine gömülerek öğretiliyor olması bakımından önemlidir. Becerinin içerisine gömülerek sunulan kavram öğretiminin öğrenciler üzerindeki olumlu etkisinin yanı sıra, birlikte öğretimin öğretmenler açısından da çeşitli yararları bulunmaktadır. Günlük yaşam becerileri ile kavramın birlikte öğretimi, öğretmenlerin daha az sürede daha fazla öğretim firsatı sunmasına olanak sağlamaktadır. Bu araştırma kavramın sadece bir günlük yaşam becerisinin içerisine gömülerek sunulmasıyla sınırlıdır. Bununla birlikte öğretmenler öğrencilerinin gereksinimleri doğrultusunda belirledikleri kavramları, birçok farklı beceri ya da rutinler içerisine gömerek öğretebilir. Ayrıca beceri öğretimlerinde kullanılan malzemeler çeşitlendirilerek ya da arttırılarak öğrencilerin farklı malzemelere genellemesi sağlanabilir.

İleri araştırmalarda bir becerinin içerisine birden fazla akademik becerinin veya birden fazla becerinin içerisine tek bir akademik becerinin gömülmesi şeklinde farklı çalışmalar yapılabilir. Ayrıca gömülü öğretimin, farklı yaş ve tanı grubundan öğrencilerle bireysel veya küçük grup etkinliklerinde günlük yaşam becerilerinin içerisine farklı kavramların gömülerek öğretimi şeklinde çeşitli araştırmalar yapılabilir. Öğretmenlere farklı mesleki gelişim modelleri ile gömülü öğretime yönelik eğitimler sağlanarak bu eğitimlerin etkililiği ve verimliliği incelenebilir. 


\section{Teşekkür ve Bilgilendirme}

Araştırma 5-8 Ekim 2016 tarihinde Anadolu Üniversitesinde gerçekleştirilmiş olan 26. Ulusal Özel Eğitim Kongresinde sözlü bildiri olarak sunulmuştur. 


\section{References}

Aldemir Fırat, Ö., \& Ergenekon, Y. (2018). Uygulamacılar için özel eğitimde farklı bir bakış açısı: Gömülü öğretim [A different perspective on special education for practitioners: Embedded instruction]. Ankara University Faculty of Education Special Education Journal of Electronic Publishing. doi: 10.21565/ozelegitimdergisi.328444

Altun-Könez, N., Çelik A., Yılmaz, B., Apaydın, G., \& Aykut, Ç. (2015). Ayrıştırılmış eğitim ortamında gömülü öğretimle sunulan kavram öğretiminin zihinsel yetersizliği olan öğrencilerin kavram edinimine etkisi [The impact of conceptual presentation of embedded instruction in the separated educational environment on the conceptualization of students with intellectual disabilities]. Report of the 25th National Special Education Congress, 73-74.

Aslan, Y., \& Eratay, E. (2009). Zihin engelli bireylere kumaş üzerine çizilen desene pul işleme becerisinin öğretiminde eşzamanlı ipucuyla öğretimin etkililiği [Effectiveness of teaching with simultaneous prompting in teaching the skill of sequin embroidering on a pattern drawn on fabric for individuals with mental disability]. Ankara University Faculty of Educational Sciences Journal of Special Education, 10(02), 015-034.

Berkeban, C. H. (2013). Gelişimsel yetersizliği olan çocuklara toplumsal uyart işaretlerinin öğretiminde gömülü ögretimle sunulan eşzamanlı ipucuyla ögretimin etkililiği (Yayımlanmamış yüksek lisans tezi). Anadolu Üniversitesi Eğitim Bilimleri Enstitüsü, Eskişehir. [Effectiveness of simultaneous prompting within embedded instruction on teaching community sight words to children with developmental disabilities] (Unpublished master's thesis, Anadolu University, Institute of Educational Sciences, Eskişehir, Turkey).

Birkan, B. (2002). Gelişim yetersizliği olan çocuklara renk öğretiminde eşzamanlı ipucuyla öğretimin etkililiği [The effectiveness of simultaneous prompting procedure on teaching colors to children with developmental disabilities]. Anadolu University Journal of Social Sciences, 2, 169-186.

Browder, D. M., Wakeman, S. Y., Flowers, C., Rickelman, R. J., Pugalee, D., \& Karvonen, M. (2007). Creating access to the general curriculum with links to grade-level content for students with significant cognitive disabilities: An explication of the concept. The Journal of Special Education, 41(1), 2-16.

Collins, B. C., Evans, A., Creech-Galloway, C., Karl, J., \& Miller, A. (2007). Comparison of the acquisition and maintenance of teaching functional and core content sight words in special and general education settings. Focus on Autism and Other Developmental Disabilities, 22(4), 220-233.

Collins, B. C., Hager, K. L., \& Galloway, C. C. (2011). Addition of functional content during core content instruction with students with moderate disabilities. Education and Training in Autism and Developmental Disabilities, 22-39.

Collins, B. C., Karl, J., Riggs, L., Galloway, C. C., \& Hager, K. D. (2010). Teaching core content with real-life applications to secondary students with moderate and severe disabilities. Teaching Exceptional Children, 43(1), 52-59.

Çifci-Tekinarslan, İ. (2015). Zihinsel yetersizliği olan öğrenciler [Students with intellectual disabilities]. İ.Diken. (Ed). Özel eğitime gereksinimi olan öğrenciler ve özel eğitim [Students with special education needs and special education]. (136-164). Ankara, Turkey: Pegem Academy.

Daugherty, S., Grisham-Brown, J., \& Hemmeter, M. L. (2001). The effects of embedded skill instruction on the acquisition of target and nontarget skills in preschoolers with developmental delays. Topics in Early Childhood Special Education, 21(4), 213-221.

Ducharme, J. M., Lucas, H., \& Pontes, E. (1994). Errorless embedding in the reduction of severe maladaptive behavior during interactive and learning tasks. Behavior Therapy, 25(3), 489-501.

Eren, B., Deniz, J., \& Düzkantar, A. (2013). Orff yaklaşımına göre hazırlanan müzik etkinlikleri içinde ipucunun giderek azaltılması yöntemi ile yapılan gömülü öğretimin otistik çocuklara kavram öğretmedeki etkililiği [The effectiveness of embedded teaching throughthe most-to-least prompting procedure in conceptteaching to 
children with autism within orff-based music activities]. Educational Sciences: Theory \& Practice, 13(3), 1863-1887.

Grisham-Brown, J., Schuster, J. W., Hemmeter, M. L., \& Collins, B. C. (2000). Using an embedding strategy to teach preschoolers with significant disabilities. Journal of behavioral education, 10(2-3), 139-162.

Horn, E., Lieber, J., Li, S., Sandall, S., \& Schwartz, I. (2000). Supporting young children's IEP goals in inclusive settings through embedded learning opportunities. Topics in Early Childhood Special Education, 20(4), 208223.

Jameson, J. M., McDonnell, J., Johnson, J. W., Riesen, T., \& Polychronis, S. (2007). A comparison of one-to-one embedded instruction in the general education classroom and one-to-one massed practice instruction in the special education classroom. Education and Treatment of Children, 30(1), 23-44.

Jameson, J. M., McDonnell, J., Polychronis, S., \& Riesen T. (2008). Embedded, constant time delay instruction by peers without disabilities in general education classrooms. Intellectual and Developmental Disabilities, 46(5), 346-363.

Johnson, J. W., \& McDonnell, J. (2004). An exploratory study of the implementation of embedded instruction by general educators with students with developmental disabilities. Education \& Treatmant of Children, 27(1), 46-64.

Johnson, J. W., McDonnell, J., Holzwarth, V. N., \& Hunter, K. (2004). The efficacy of embedded instruction for students with developmental disabilities enrolled in general education classes. Journal of Positive Behavior Interventions, 6(4), 214-227.

Karabulut, A., \& Yıkmış, A. (2010). Zihin engelli bireylere saat söyleme becerisinin öğretiminde eşzamanlı ipucuyla öğretimin etkililiği [The effectiveness of simultaneous prompting on teaching the skill of telling the time to individuals with mental retardation]. Abant İzet Baysal University Journal of Education Faculty, 10(2).

Karl, J., Collins, B. C., Hager, K. D., \& Ault, M. J. (2013). Teaching core content embedded in a functional activity to students with moderate intellectual disability using a simultaneous prompting procedure. Education and Training in Autism and Developmental Disabilities, 363-378.

Kurt, O., \& Tekin-İftar, E. (2008). A comparison of constant time delay and simultaneous prompting within embedded instruction on teaching leisure skills to children with autism. Topics in Early Childhood Special Education, 28(1), 53-64.

Odluyurt, S. (2011). Etkinlikler içine gömülen sabit bekleme süreli öğretimin gelişimsel yetersizliği olan küçük çocuklara giysi isimlendirme becerisinin öğretimi üzerindeki etkililiği [The effects of constant time delay embedded into teaching activities for teaching the names of clothes for preschool children with developmental disabilities]. Educational Sciences: Theory \& Practice, 11(3), 1445-1460.

Odluyurt, S., \& Batu, S. (2010). Gelişimsel yetersizlik gösteren çocuklara kaynaştırmaya hazırlık becerilerinin öğretimi [Teaching inclusion preparation skills to children with developmental disabilities]. Educational Sciences: Theory \& Practice, 10(3),1533-1572.

Özak H., \& Diken İ.H., (2010). Zihinsel yetersizliği olan öğrencilerin işlevsel akademik becerilerine ilişkin Türkiye'de yapılan lisansüstü tezlerin gözden geçirilmesi [Functional Academic Skills of Intellectual Disabilities Students Graduate Investigation About Reviews for Thesis in Turkey]. Ankara University Faculty of Educational Sciences Journal of Special Education, 11(01), 043-058.

Özyürek, M. (1983). Kavram öğrenme ve öğretme [Concept learning and teaching]. Ankara University Journal of Educational Sciences, 2, 347-366.

Pretti-Frontczak, K., \& Bricker, D. (2001). Use of the Embedding Strategy during Daily Activities by Early Childhood Education and Early Childhood Special Education Teachers. Infant-Toddler Intervention: The Transdisciplinary Journal, 11(2), 111-28.

Pretti-Frontczak, K., \& Bricker, D. (2004). An activity-based approach to early intervention. Brookes Publishing Company. PO Box 10624, Baltimore, MD 21285. 
Rakap, S., \& Balikci, S. (2016). Using embedded instruction to teach functional skills to a preschool child with autism. International Journal of Developmental Disabilities, 63(1), 17-26.

Riesen, T., McDonnell, J., Johnson, J. W., Polychronis, S., \& Risen, T. (2002). Effects of embedded instruction on students with moderate disabilities enrolled in general education classes. Education and Training in Mental Retardation and Developmental Disabilities, 363-377.

Simpson, K., \& Keen, D. (2010). Teaching young children with autism graphic symbols embedded within an interactive song. Journal of Developmental and Physical Disabilities, 22(2), 165-177.

Snell, M. E., \& Brown, F. (2000). Development and implementation of educational programs. Instruction of students with severe disabilities, 5, 115-172.

Sucuoğlu, B. (2009). Zihin engelliler ve eğitimleri [Intellectual disabiled and educated]. Ankara, Turkey: Kök Publishing.

Şahin, Ş. (2015). Otizmli çocuklara toplumsal uyart işaretlerinin öğretiminde geleneksel ve gömülü öğretimle sunulan sabit bekleme süreli ögretimin etkililik ve verimliliklerinin karşılaştırılması (Yayımlanmamış yüksek lisans tezi). Anadolu Üniversitesi Eğitim Bilimleri Enstitüsü, Eskişehir. [A comparison of the traditionally presented constant time delay intruction and constant time delay instruction with embedded teaching on teaching community alert signs to children with autism spectrum disorders] (Unpublished master's thesis). Anadolu University, Institute of Educational Sciences, Eskişehir, Turkey.

Tawney, J., \& Gast, D. (1984). Single subject research in special education. Upper Saddle River, NJ: Merrill.

Tekin, E., \& Kircaali-Iftar, G. (2001). Özel eğitimde yanlıssız öğretim yöntemleri [Errorless teaching procedures in special education]. Ankara, Turkey: Nobel Publishing.

Tekin-İftar, E. (2018). Eğitim ve davranış bilimlerinde tek-denekli araştırmalar [Single subject research in education and behavioral sciences]. Ankara, Turkey: Anı Publishing.

Varol, N. (2005). Beceri öğretimi ve öz bakım becerilerinin kazandırılması [Skill teaching and to gain self-care skills]. Ankara, Turkey: Kok Publishing.

Wolery, M., Doyle, P. M., Gast, D. L., \& Ault, M. J. (1993). Comparison of progressive time delay and transitionbased teaching with preschoolers who have developmental delays. Journal of Early Intervention, 17(2), 160176.

Wolery, M., Anthony, L., Caldwell, N. K., Snyder, E. D., \& Morgante, J. D. (2002). Embedding and distributing constant time delay in circle time and transitions. Topics in Early Childhood Special Education, 22(1), 14-25. 